\title{
Translational Research in Genomics of Alzheimer's Disease: A Review of Current Practice and Future Perspectives
}

\author{
Raluca Mihaescu ${ }^{\mathrm{a}}$, Symone B. Detmar ${ }^{\mathrm{b}}$, Martina C. Cornel ${ }^{\mathrm{c}}$, Wiesje M. van der Flier ${ }^{\mathrm{d}}$, Peter Heutink ${ }^{\mathrm{e}}$, \\ Elly M. Hol ${ }^{\mathrm{f}}$, Marcel G.M. Olde Rikkert' ${ }^{\mathrm{g}}$, Cornelia M. van Duijn ${ }^{\mathrm{a}}$ and A. Cecile J.W. Janssens ${ }^{\mathrm{a}, *}$

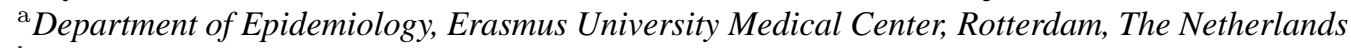 \\ ${ }^{\mathrm{b}}$ TNO Quality of Life, Leiden, The Netherlands \\ ${ }^{\mathrm{c}}$ Community Genetics, Department of Clinical Genetics/EMGO Institute, VU University Medical Center, \\ Amsterdam, The Netherlands \\ ${ }^{\mathrm{d}}$ Alzheimer Center and Department of Neurology, Department of Epidemiology and Biostatistics, VU University \\ Medical Center, Amsterdam, The Netherlands \\ ${ }^{\mathrm{e}}$ Department of Clinical Genetics, Section of Medical Genomics, VU University Medical Center, Amsterdam, The \\ Netherlands \\ ${ }^{\mathrm{f}}$ Department of Astrocyte Biology \& Neurodegeneration, Netherlands Institute for Neuroscience, Institute of the \\ Royal Netherlands Academy of Arts and Sciences, Amsterdam, The Netherlands \\ ${ }^{g}$ Department of Geriatrics, Alzheimer Center Nijmegen, Radboud University Hospital Nijmegen, Nijmegen, The \\ Netherlands
}

Handling Associate Editor: Inga Zerr

Accepted 4 January 2010

\begin{abstract}
Alzheimer's disease (AD) is the most prevalent form of dementia and the number of cases is expected to increase exponentially worldwide. Three highly penetrant genes (A $\beta P P, P S E N 1$, and PSEN2) explain only a small number of AD cases with a Mendelian transmission pattern. Many genes have been analyzed for the association with non-Mendelian AD, but the only consistently replicated finding is $A P O E$. At present, possibilities for prevention, early detection, and treatment of the disease are limited. Predictive and diagnostic genetic testing is available only in Mendelian forms of AD. Currently, APOE genotyping is not considered clinically useful for screening, presymptomatic testing, or clinical diagnosis of non-Mendelian AD. However, clinical management of the disease is expected to benefit from the rapid pace of discoveries in the genomics of AD. Following a recently developed framework for the continuum of translation research that is needed to move genetic discoveries to health applications, this paper reviews recent genetic discoveries as well as translational research on genomic applications in the prevention, early detection, and treatment of AD. The four phases of translation research include: 1) translation of basic genomics research into a potential health care application; 2) evaluation of the application for the development of evidence-based guidelines; 3) evaluation of the implementation and use of the application in health care practice; and 4) evaluation of the achieved population health impact. Most research on genome-based applications in AD is still in the first phase of the translational research framework, which means that further research is still needed before their implementation can be considered.
\end{abstract}

Keywords: Alzheimer's disease, genomics, review, translational research

${ }^{*}$ Correspondence to: A. Cecile J.W. Janssens, Department of Epi$\overline{\text { demiology, Erasmus University Medical Center, Postbox 2040, } 3000}$ 


\section{INTRODUCTION}

Alzheimer's disease (AD) is the most common cause of dementia and the most frequent neurodegenerative disorder associated with aging. Currently, 5.3 million Americans are diagnosed with AD, accounting for 60$80 \%$ of all dementia cases in US [1]. As a result of the aging population, the number of patients with $\mathrm{AD}$ is expected to increase exponentially [2].

Rapid advances in genomics of AD have fueled enormous expectations about future use of susceptibility variants for prevention, diagnosis, and treatment of the disease [3]. Evidence for a strong genetic contribution has consistently been documented in twin and familybased linkage studies. Heritability estimates from a large twin study suggest that genetic variations may account for about $58 \%$ to $80 \%$ of AD risk and a few variants for monogenic subtypes have been identified [4]. Large numbers of susceptibility genetic variants are investigated for their putative association with $\mathrm{AD}$ and a plethora of translational research exists. With respect to $\mathrm{AD}$, genome-based tests potentially can improve the diagnosis, prognosis or prediction, and treatment of AD.

A clinical diagnosis of AD is based on clinical examination and neuropsychological testing, and mainly involves the exclusion of other causes of dementia. Facilitated by the neuropsychological and structural neuroimaging advances, the accuracy of the clinical diagnosis has increased to 80-90\% [5], but a definite diagnosis still awaits neuropathological confirmation. Genome-based tests and improved imaging are envisioned to improve the differential diagnosis and to provide a basis for disease subtypes characterization.

Predicting the development and prognosis of $\mathrm{AD}$ is difficult because the disease has a complex etiology with genetic and environmental factors playing an intricate role. The lifetime risk in individuals who have a first-degree relative with late onset $\mathrm{AD}$ was evaluated to be about 2 to 4 times higher than in individuals without affected first-degree relatives [6]. The incidence of $\mathrm{AD}$ increases from 1.2 per 1000 person years in the 65-69 years age group to 53.5 per 1000 person years in the older than 90-year age group [7]. Advanced age and positive family history are the only risk factors which have become firmly established [8,9]. There also seems to be a gender distribution of risks for $\mathrm{AD}$,

CA Rotterdam, The Netherlands. Tel: +31 10704 4232; Fax: +31 10704 4657; E-mail: a.janssens@erasmusmc.nl. with a higher prevalence of dementia in women than in men, predominantly after age $75[2,8]$. Genetic testing is investigated for identifying at risk individuals before the clinical onset of disease, given that preventive measures will be proven to be efficacious.

Currently available treatment is symptomatic and cannot delay progression of the neurodegenerative process. Cholinesterase inhibitors (donezepil, rivastigmine, and galantamine) and the NMDA partial antagonist memantine are used for the management of the cognitive symptoms, but these agents are moderately effective in $30 \%$ to $40 \%$ of mild-to-moderate AD patients with side-effects, intolerance, and noncompliance in $>$ $60 \%$ of treated individuals [10-12]. Additionally, neuroleptic and antidepressant medication is often used for associated psychiatric symptoms. Several Phase I, II, and III clinical trials that investigate new therapeutic strategies, such as $\gamma$-secretase modulators, amyloid- $\beta$ aggregation inhibitors, passive and active vaccination, and light therapy, have shown improvement of cognitive function $[13,14]$. It is envisioned that genomebased tests can identify subgroups of patients in which the specific therapies may be effective.

In the past few years, there has been increasing interest in investigating the potential clinical and public health applications of genetic tests in AD. This review summarizes the recent advances in translational research, following the framework for the continuum of translation research described by Khoury and colleagues [15]. This framework specifies four stages of scientific evidence in translation research and therewith identifies the most likely applications of genetic testing in the clinical management of $\mathrm{AD}$ in the near future. The paper starts with a review of genetic discoveries in $\mathrm{AD}$ and presents the future applications against the current place of genetic testing in the prediction, diagnosis and treatment of AD.

To identify applicable articles, we performed a search for publications in MEDLINE from January 2006, and in the lists of references from retrieved articles. We used a combination of the following keywords: "Alzheimer", "genetic", "genomic", "screening", "prognosis", "prediction", "diagnosis", "therapy", "treatment”, “intervention”, “risk”, “advances”, "trend", "innovation”, "progress", “emerging”, "development", "insight", "utility", "guideline", "decision making", "state medicine", "translational medicine", and "translational research". We considered for inclusion in our analysis: editorials, reviews, meta-analyses, original scientific papers published in peer-review journals, and evidence-based practice guidelines. A draft report was written and discussed in an expert meeting to verify and complete all retrieved information. 
Table 1

Mutations in families with autosomal dominant Alzheimer's disease (AD)

\begin{tabular}{|c|c|c|c|c|c|c|}
\hline Gene & Penetrance & Chromosome & $\begin{array}{l}\text { Frequency of mu- } \\
\text { tation in families } \\
\text { with autosomal } \\
\text { dominant AD }\end{array}$ & $\begin{array}{l}\text { Number of } \\
\text { pathogenic } \\
\text { mutations* }\end{array}$ & Age of onset & References \\
\hline \multicolumn{7}{|l|}{ Established Factors } \\
\hline PSEN1 & Complete & $14 \mathrm{q} 24.3$ & $20-70 \%$ & 177 & $28-50$ years & {$[16,81]$} \\
\hline$A \beta P P$ & Complete & $21 q 21$ & $10-15 \%$ & 32 & $45-65$ years & {$[16,81]$} \\
\hline PSEN2 & Incomplete & $1 q 31-q 42$ & Rare & 14 & $40-85$ years & {$[16,81]$} \\
\hline \multicolumn{7}{|l|}{ Investigated Factors } \\
\hline$P G R N$ (progranulin gene) & Incomplete & $17 q 21-22$ & Rare & 68 & $35-89$ years & {$[82]$} \\
\hline$M A P T$ (Tau gene) & Complete & $17 q 21.1$ & Rare & 44 & $40-60$ years & {$[83]$} \\
\hline
\end{tabular}

*From Alzheimer's Disease \& Frontotemporal Dementia Database website [21].

\section{GENETICS OF AD}

From a genetic perspective, a distinction is made between Mendelian and non-Mendelian forms of AD. Only a small percentage of cases present with a Mendelian transmission pattern and a disease onset generally before 60-65 years (early-onset Alzheimer's disease, EOAD). Most AD cases present with a non-Mendelian transmission pattern and have an older age at diagnosis (late-onset Alzheimer's disease, LOAD). LOAD is mostly sporadic, but in approximately $25 \%$ of cases with LOAD, another affected relative can be identified [16]. Non-Mendelian AD is considered to be etiologically more complex than Mendelian AD and may involve multiple susceptibility genes that interact with other genes and with environmental risk factors. The distinction between EOAD and LOAD, however, is arbitrary, since clinical and pathological features are similar in both groups, and it is no longer used by most experts.

So far, three causal genes have been identified in a few hundreds of families in the world, which together account for a small percentage of Mendelian AD: amyloid- $\beta$ protein precursor $(A \beta P P)$ gene on chromosome 21 [17], presenilin 1 (PSEN1) gene on chromosome 14 [18], and presenilin 2 (PSEN2) gene on chromosome 1 (Table 1) [19,20]. These genes are not found in non-Mendelian AD [21]. Almost all carriers of a mutation in the $A \beta P P$ or PSEN1 genes will eventually develop the disease, but the mutations in the PSEN2 gene are not completely penetrant with carriers showing large variations in the age of onset [22].

To date, the most commonly replicated genetic risk factor for sporadic $\mathrm{AD}$ is the gene coding for the apolipoprotein E, located on chromosome 19 [23]. Three common alleles of the APOE gene have been identified: $\varepsilon 2, \varepsilon 3$, and $\varepsilon 4$. The $A P O E \varepsilon 4$ allele is more frequent in patients with non-Mendelian $\mathrm{AD}$, compared to controls [24]. About half of the patients with sporadic $\mathrm{AD}$ carry an $A P O E \& 4$ allele [25]. The $A P O E$ gene is moderately penetrant, with each additional copy of the $\varepsilon 4$ allele increasing the risk of $\mathrm{AD}(\mathrm{OR}=2$ to 8 depending on the population studied) and correlating with a slightly younger age at dementia onset $[25,26]$. In individuals with a positive family history, the risk of $\mathrm{AD}$ for carriers of a single $A P O E \varepsilon 4$ allele was estimated to be 3 times higher compared to other $A P O E$ genotypes, and carrying two $\varepsilon 4$ alleles was associated with a 15 to 30 fold increase in risk of AD [27]. The association between $A P O E \varepsilon 4$ allele and $\mathrm{AD}$ is stronger among women than among men [25]. Although the association between $A P O E \varepsilon 4$ and the risk of $\mathrm{AD}$ is evident in all ages between 40 and 90 years, it becomes weaker after the age of 70 years [25].

In the past decades, numerous studies have tried to identify susceptibility genes for AD investigating hundreds of putative risk alleles in more than 500 genes [28]. The genome-wide association studies (GWAS) performed in the field of AD research confirmed the $A P O E$ locus as the major susceptibility gene for non-Mendelian AD [29]. All other newly identified susceptibility genes each confer only a small increase in disease risk (Table 2) [30], and altogether explain only a small part of the genetic risk of AD. Based on evidence from meta-analyses of genetic association studies, several genes are considered candidates for association with AD risk (Table 3) [28]. To be noted, however, the very modest relative risks which confirm the expectations that probably no other single gene will account for a high percentage of non-Mendelian AD. Improvements in the characterization of patients, e.g., by further distinction of subtypes, may still uncover other strong genetic variants, and strong effects might be expected from gene-gene and gene-environment interactions. 


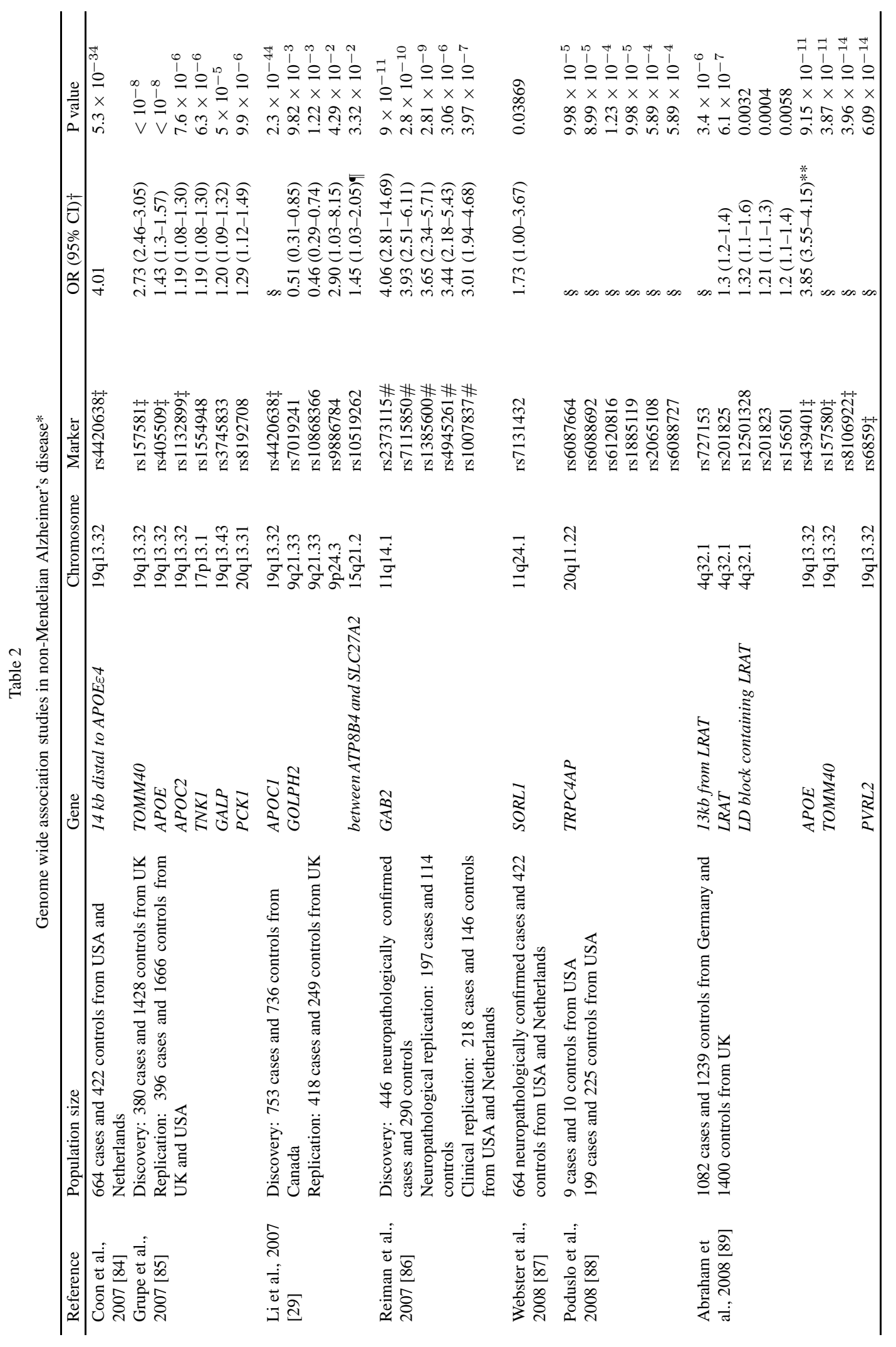




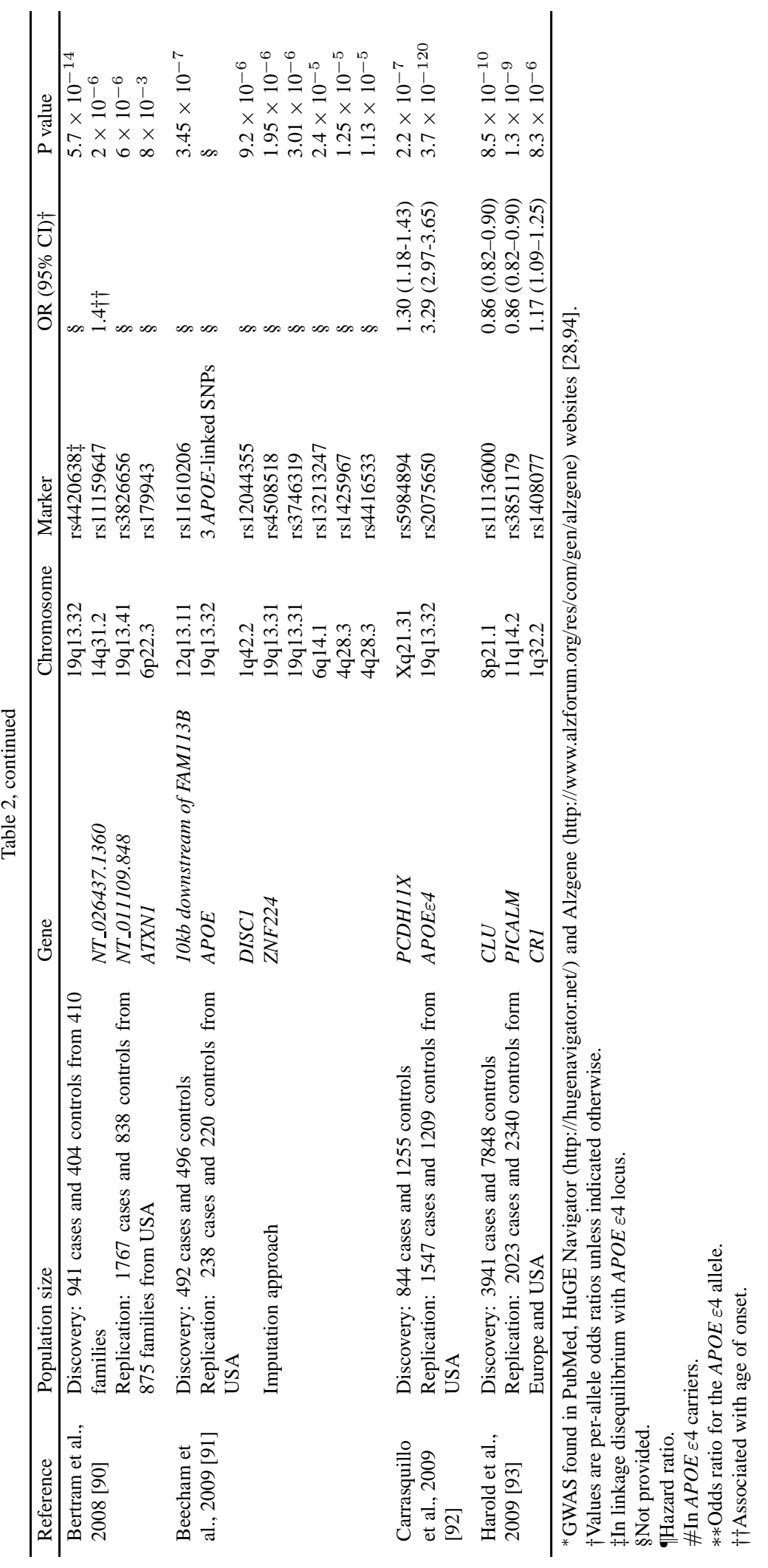


Table 3

Top ten non-Mendelian Alzheimer's disease genes from meta-analyses of four or more independent samples [28]

\begin{tabular}{lllccc}
\hline Gene & SNP & Population & $\begin{array}{c}\text { Associated } \\
\text { allele* }\end{array}$ & Effect size ${ }^{\dagger}$ & $\begin{array}{c}\text { Total size (cases } \\
\text { \& controls) }\end{array}$ \\
\hline APOE & ApoE & Caucasian & ApoE $\varepsilon 4$ vs. $\varepsilon 3$ & $3.81(3.38-4.29)$ & 7812 \\
$(\varepsilon 2 / 3 / 4)$ & $\varepsilon 2 / 3 / 4$ & & ApoE $\varepsilon 2$ vs. $\varepsilon 3$ & $0.56(0.40-0.79)$ & \\
$C L U$ & rs11136000 & All & T & $0.85(0.82-0.89)$ & 26246 \\
$P I C A L M$ & rs541458 & All & C & $0.87(0.83-0.91)$ & 21915 \\
$T N K 1$ & rs1554948 & All & A & $0.86(0.80-0.93)$ & 5727 \\
$A C E$ & rs1800764 & Caucasian & C & $0.79(0.68-0.92)$ & 1565 \\
$T F A M$ & rs2306604 & All & G & $0.82(0.72-0.94)$ & 1851 \\
$C S T 3$ & rs1064039 & Caucasian & A & $1.16(1.00-1.33)$ & 3014 \\
$I L 1 B$ & rs1143634 & Caucasian & T & $1.18(1.04-1.35)$ & 2255 \\
$C R 1$ & rs6656401 & Caucasian & A & $1.19(1.09-1.28)$ & 17181 \\
$h C G 2039140$ & rs1903908 & Caucasian & T & $1.23(1.06-1.44)$ & 2865 \\
\hline
\end{tabular}

*When effect size is $<1.00$ allele is protective.

${ }^{\dagger}$ Effect size expressed as per allele odds ratios.

\section{CURRENT APPLICATIONS OF GENETIC TESTING}

A number of evidence-based guidelines of genetic testing in AD are currently available [31-33]. At present, genetic testing is mainly used for monogenic forms of $\mathrm{AD}$, solely in presymptomatic and diagnostic settings and so far has no application in therapeutic strategies.

\section{Presymptomatic testing}

Presymptomatic testing for mutations in $A \beta P P$, PSEN1, and PSEN2 genes can be performed in the presence of a positive family history of autosomal dominant inheritance and if a mutation is documented in an affected relative [33,34]. Criteria for the definition of a positive family history are, however, unclear. Prenatal diagnosis and preimplantation genetic diagnosis (PGD) are two options available for families with autosomal dominant disease with a documented causal mutation [35]. Prenatal diagnosis establishes the carrier status in an offspring during the pregnancy, whereas PGD consist of testing the embryos before the pregnancy is established [36,37]. Presymptomatic testing in children of adults with known mutations is not encouraged because of ethical and psychological concerns [31].

Presymptomatic genetic testing is available only for monogenic forms of disease. APOE genotyping for presymptomatic testing of non-Mendelian AD is not recommended, because the sensitivity and specificity of $A P O E$ testing with respect to detection of individuals at risk for $\mathrm{AD}$ are too low, i.e., not all patients with $\mathrm{AD}$ carry the $\varepsilon 4$ allele and not all $\varepsilon 4$ carriers will develop $\mathrm{AD}[33,34]$. APOE genotyping is discouraged because of the presumed psychological harm, the impact on the relatives of a patient carrying two $A P O E \varepsilon 4$ alleles, and the lack of specific treatment for individuals at genetic risk [38]. However, despite the scarce evidence to support the role of predictive genetic testing for $\mathrm{AD}$, several commercial companies already offer direct-toconsumer testing to predict risk of $\mathrm{AD}$, basing their prediction on testing the $A P O E$ related single-nucleotide polymorphisms [39]. The Risk Evaluation and Education for Alzheimer's Disease (REVEAL) study evaluated the 1 year effect of $A P O E$ genotype disclosure to adults with a parent with $\mathrm{AD}$ and found no difference between levels of anxiety and depression between individuals who received and those who did not receive APOE genotype disclosure [40]. However, effects may differ with longer follow-up and outside research settings, when it is unknown if people receive information about the limitations of single genetic tests [41].

\section{Diagnosis}

Differential diagnosis in patients with clinical diagnosis of $\mathrm{AD}$ and a family pattern of autosomal dominant inheritance may involve testing for known pathogenic mutations [33]. Testing for common mutations in A $\beta P P, P S E N 1$, and PSEN2 genes can also be considered in cases presenting with clinical symptoms of dementia at younger age but without a positive family history [42]. Genetic testing is also done postmortem in families with autosomal dominant disease to assist the future diagnosis of at risk relatives [33].

$A P O E$ testing is considered potentially useful to identify the cause of a dementia syndrome, i.e., to test whether the dementia is caused by AD. However, genetic testing for $A P O E$ gene is not part of the routine 
Table 4

Developments in genomics research in Alzheimer's disease (AD) according to the framework for translation research [15]

\begin{tabular}{|c|c|c|c|c|}
\hline & $\begin{array}{l}\text { Discovery to candidate health } \\
\text { application }\end{array}$ & $\begin{array}{l}\text { Health application to evidence- } \\
\text { based practice guidelines }\end{array}$ & $\begin{array}{l}\text { Practice guide- } \\
\text { lines to health } \\
\text { practice }\end{array}$ & $\begin{array}{l}\text { Practice } \\
\text { to population } \\
\text { health impact }\end{array}$ \\
\hline $\begin{array}{l}\text { Presymptomatic } \\
\text { Testing }\end{array}$ & $\begin{array}{l}\text { Prediction of AD and predementia } \\
\text { using prediction models with ge- } \\
\text { netic and non-genetic risk factors }\end{array}$ & $\begin{array}{l}\text { APOE testing to identify high-risk } \\
\text { groups: clinical validity, attitudes, } \\
\text { behavioral change and psycholog- } \\
\text { ical impact }\end{array}$ & None & None \\
\hline Prevention & None & None & None & None \\
\hline Diagnosis & $\begin{array}{l}\text { Clinical validity of } A P O E \text { testing } \\
\text { for more accurate dementia diag- } \\
\text { nosis in sporadic cases }\end{array}$ & None & None & None \\
\hline Therapy & $\begin{array}{l}\text { Pharmacogenetics: } \\
\text { - Interaction between genetic fac- } \\
\text { tors and treatment } \\
\text { - Genetic profiles for prediction of } \\
\text { treatment results }\end{array}$ & None & None & None \\
\hline
\end{tabular}

laboratory investigations during the differential diagnosis of dementia, because the positive and negative predictive values of the test are too low [32].

\section{TRANSLATIONAL GENOMIC RESEARCH IN} AD

Although only limited opportunities are available for genetic testing in the prevention, early detection, and treatment of $\mathrm{AD}$, there is extensive ongoing research aiming at integrating the genetic discoveries into clinically useful tools. It has been acknowledged that several research stages are required before genetic discoveries can be implemented into health care. Khoury and colleagues have described a framework for the continuum of translational research that is required to move genomics research findings to clinical and public health applications that benefit population health [15]. The four phases of translation research include: 1) translation of basic genomics research into a potential health care application; 2) evaluation of the application for the development of evidence-based guidelines; 3) evaluation of the implementation and use of the application in health care practice; and 4) evaluation of the achieved population health impact [15]. Thus, the framework indicates how close a genetic application is to clinical and public health practice. The major developments in genomics of $\mathrm{AD}$, for each phase of translation research, are summarized in Table 4.

\section{Discovery to candidate health application}

Examples of relevant candidate health applications in AD research are the development of single gene tests and construction of genomic profiles, to be used for prediction, screening, diagnosis, and targeted treatment of the disease. The aim of phase one translation research is to determine the sensitivity, specificity, and positive predictive value of the genetic tests for these applications [15].

\section{Genome-based prediction of $A D$}

Apart from testing for monogenic subtypes in high risk patients, where clinical utility is clear, genetic prediction of complex diseases consists of testing multiple genes, or multiple genes added to traditional risk factors. A recent study suggested that polymorphisms in 10 genes (APOE, LDLr, CST3, CTSD, TNF, BACE1, $M A P T, S T H, e N O S, T F C P 2)$ may help to distinguish among three clusters of patients with non-Mendelian AD: a young group of 60-69 years with a risk allele on genes related to plaque deposition, a second group of 70-80 years and risk alleles on genes related to neurofibrillary tangles formation, and a third group of $<$ 65 and 70-85 years and risk alleles on inflammation genes [43]. Other case-control studies have identified AD-risk profiles based on clusters of genes related to cholesterol or inflammation with promising predictive values [43-47]. Further research is needed to validate whether these genomic profiles can prospectively identify individuals at risk to develop AD.

To date, only a few studies have included multiple variants in $\mathrm{AD}$ prediction models, but most have considered only the APOE genotype among other nongenetic risk predictors. An example of AD risk prediction model that incorporates APOE status is the development of risk curves specific to ethnicity, age, gender, and $A P O E$ genotype from the REVEAL study [48]. Motivated by an increased risk for AD in African Amer- 
icans, and after a careful evaluation of ethical principles, separate risk curves were constructed for white and African American first-degree relatives of patients with AD. Cumulative risk curves stratified by ethnicity and genotype showed that risk was lower than $10 \%$ until age 60, afterwards the risk increased for all ethnic groups but more steeply with African American ethnicity and $A P O E \varepsilon 4$ genotype [48]. Moreover, observational studies and randomized control trials have shown that environmental risk factors such as physical inactivity, dietary fat intake, alcohol drinking, smoking at midlife, diabetes, and traumatic brain injury were stronger associated with dementia and $\mathrm{AD}$ among $A P O E \varepsilon 4$ carriers than in non-carriers, indicating an interaction effect between these two factors [49,50].

Finally, prospective cohort studies indicated that genetic testing for APOE could be useful in selecting patients at risk of progression from mild cognitive impairment (MCI) to dementia, but further studies are needed to demonstrate the beneficial impact of this risk information [35,51]. For example, a longitudinal study that uncovered an increased association between $A P O E \varepsilon 4$ carrier status and conversion to $\mathrm{AD}$ in older individuals with MCI failed to prove $A P O E \varepsilon 4$ carrier status useful to predict conversion of MCI to $\mathrm{AD}$ [52].

\section{Genetic testing to improve diagnostic accuracy}

Genetic tests may add to other laboratory tests commonly used to identify whether the dementia is due to AD. A large study that assessed the clinical validity of adding the $A P O E$ status to the clinical diagnosis showed that the area under the ROC curve (AUC) increased from 0.84 based on clinical factors to 0.87 when APOE was added to the clinical factors [5]. This difference in AUCs was statistically significant, suggesting that genotyping for $A P O E$ provides additional information in patients who meet the clinical criteria for AD.

Genetic risk factors are also used in research settings to uncover the biological markers related to sub-clinical stages of the disease. The correlation between APOE genotypes and different endophenotypes were investigated by a number of prospective clinical multicentre trials which aimed to find new variables for detection of preclinical AD [51,53,54]. These studies suggested that $A P O E \quad \varepsilon 4$ genotype correlates most strongly with the cerebrospinal fluid levels of amyloid- $\beta$ protein 42 amino acid form, cerebral glucose metabolism, and quantitative EEG (i.e., decreased alpha rhythm during rest and dysfunction of deep brain structures during hyperventilation). Another example comes from a study that tested 500 transcripts of $\mathrm{AD}$ associated genes for their use in prediction of incipient $\mathrm{AD}$ [55]. In two datasets of around 30 postmortem brain samples each from the hippocampus (i.e., Blalock dataset) and the entorhinal cortex (i.e., Dunckley dataset), increased or decreased amounts of specific gene products were consistently found in individuals with incipient $\mathrm{AD}$ (i.e., Braak stages III-IV), indicating that testing for these genes may be useful in identifying individuals at subclinical stages of the disease [55].

\section{Genome-based prediction of treatment response}

Genetic testing can improve the treatment by increasing drug efficacy and safety. Also, genetic tests can be used to select patients for therapies that target specific genes or gene products. Several recent studies of pharmacogenomic research in AD have suggested that therapeutic response to cholinergic agents might depend on genotype at APOE, PSEN1, PSEN2, and CYP2D6 genes, however, results are conflicting [12, $51,56]$. For example, some studies reported worse response to cholinergic enhancers in $A P O E \varepsilon 4$ carriers, but others found no association between the APOE genotype and response to galantamine [51]. However, recent studies showed that $A P O E$ genotype is correlated to clinical phenotype in terms of cognitive impairment in $\mathrm{AD}$, supporting the existence of different subtypes of $\mathrm{AD}$ that may influence therapeutic response [57-59]. In addition, studies of neurotransmitter genes suggest that neuroleptic and antidepressant medication may be effective in selected groups of patients based on their genetic profile $[51,60]$. For example, variants in dopamine 2 and serotonin $2 \mathrm{~A}$ receptors have been associated with early response to neuroleptics and response to clozapine and risperidone, respectively [60].

Clinical trials of new therapeutic strategies may also benefit from genetic testing. Combining APOE status with information from neuroimaging studies has proven to be a useful strategy for early detection of subtle brain abnormalities that may precede more advanced stages of $\mathrm{AD}$ (i.e., $4 \%$ left posterior cingulated metabolic decline at 2 years follow-up in $A P O E$ $\varepsilon 4$ carriers), suggesting that a combination of genetic variants and cerebral metabolic rates may be useful in monitoring experimental treatment response [61].

Apart from modifying the efficacy of available drugs, the discovery of new variants has also led to the development of drug treatments that target specific genes. For example, risk profile carrier status on genes related to inflammation or estrogen metabolism may determine the response to therapeutic strategies in these 
pathways. Studies of genetic profiles of immune related gene polymorphisms indicated that only patients with early onset $\mathrm{AD}$ and fast clinical deterioration show definite pro-inflammatory genetic profiles, suggesting that anti-inflammatory drugs may be especially useful in these patients [62]. Considering the role of estrogens in the pathology of AD and the differences in vulnerability to cognitive dysfunctions in women, other groups have looked at the genetic variability in estrogen receptors [63]. Polymorphisms in estrogen receptors $\alpha$ and $\beta$ were associated with an increased risk of $\mathrm{AD}$, with a recent study showing that estrogen receptor $\alpha$ splice variants expression pattern changes with aging and in $\mathrm{AD}[63,64]$. Observational studies and metaanalyses suggested a neuroprotective effect of the hormone replacement therapy [63], but this failed to be confirmed by a large RCT trial that was stopped due to an increased risk for breast cancer and stroke in the treatment groups [65].

Finally, Phase I and II clinical trials evaluate a large number of disease modifying drugs, many of them targeting the amyloid- $\beta$ pathway $[66,67]$. Most of these drug trials also evaluate genetic markers among other baseline characteristics of the subjects enrolled in the study, and this may provide further insight on genetic variation associated with treatment response. For example, a Phase II clinical trial of the PPAR $\gamma$ agonist rosiglitazone showed improvement in cognitive functioning in treated patients compared to placebo, but only if they were non-carriers of the APOE $\varepsilon 4$ allele [68]. Similar results were reported in trials of the anti-amyloid- $\beta$ monoclonal antibody bapineuzum$\mathrm{ab}$ [69] and the ketogenic compound AC-1202 [70], indicating that $A P O E$ genotyping is relevant in pharmacogenomic research. Conversely, studies which aim to identify risk profiles (i.e., inflammatory profiles comprised of alleles of pro/anti-inflammatory cytokines) will potentially allow both the early identification of individuals susceptible of developing $\mathrm{AD}$ and the possible design or utilization of a drug with enhanced safety [71].

\section{Health application to evidence-based practice guidelines}

The second phase of translation research starts after there is convincing evidence on genetic tests performance. In this phase, the clinical validity and utility of genetic tests are measured in the population settings for which the tests are primarily intended. Results from the second phase of translation research should lead to evidence based reviews and guidelines for clinical and public health practice [15]. Although there is increasing use of genetic testing for clinical and scientific use, current practices vary across memory research centers.

To date, all guidelines recommend against $A P O E$ genotype testing for screening, early detection, or diagnosis of AD due to a low sensitivity, specificity, and positive predictive value and the possible negative health outcomes associated with testing. However, recent data from the REVEAL study showed that APOE genotype disclosure in adult children of patients with $\mathrm{AD}$ has no negative short-term psychological impact in carriers and non-carriers of the risk allele [40]. This is in line with the findings reported by a systematic review of psychological and behavioral consequences of genetic testing [72].

Assessment of social and behavioral issues linked to genetic tests is an important aspect of second phase of translation research. The REVEAL study showed that women, highly educated persons, and persons below 60 seemed to be more interested in genetic testing for $\mathrm{AD}$, and that primary motivation for undertaking the tests were advance planning and emotional coping with the threat of disease [73]. Health behavior analyses in the REVEAL study suggested that disclosing increased risk status can motivate adoption of activities believed to lower the risk of $\mathrm{AD}$, such as dietary and lifestyle changes [73].

\section{Practice guidelines to health practice and practice to population health impact}

The third phase of translation research addresses the spreading and integration of knowledge gained through the second phase research. It involves both public and professional/private participation for adoption of proved genomic application [15]. The fourth phase of translation research focuses on clinical and public health outcomes of adopted guidelines and includes measures of disease incidence, quality-of-life indicators, clinical decision modeling, and cost-effectiveness analysis, among others [15].

Currently, there is limited data available on the implementation of the novel genomic applications into health practice. As most of translation research in AD is still in the first phase, studies that assess the population health impact are limited to Mendelian $\mathrm{AD}$, if available at all. 


\section{CONCLUSION}

AD shows typical characteristics of a Mendelian disorder in a small number of cases, however, in most cases, $\mathrm{AD}$ is a complex disorder in which gene-gene and gene-environment interaction play a major role. To date, diagnosis is usually made after the disease processes are likely to be irreversible and therapeutics of AD includes only symptomatic drugs that cannot halt the disease progress. Much hope is placed on the genomic discoveries in $\mathrm{AD}$ which are expected to improve presymptomatic testing, diagnosis, and treatment of $\mathrm{AD}$. In this review we have summarized the current use of genomic information in the clinical management of $\mathrm{AD}$ and described the most likely future applications in the context of the four translational research phases in genomics of AD. Relevant literature was retrieved from a MEDLINE search, and included editorials, reviews, meta-analyses, original scientific papers published in peer-review journals, and evidence-based practice guidelines subsequently discussed in an expert meeting.

Many genes are analyzed for the association with sporadic AD, but the only consistently replicated finding is the $A P O E$ gene, which is found in almost half of the sporadic cases. Given the small predictive value of genetic testing for $A P O E$, it is not considered clinically useful for screening, presymptomatic testing, or clinical diagnosis. All genes identified through GWAS have small effects on disease risk and none of them can be used individually for screening or predictive testing. Instead, testing at multiple loci is evaluated for its role in identifying people at higher risk of developing AD.

Whether genetic profiling can be useful depends on many factors that influence its clinical validity and utility. It has been previously shown that the discriminative accuracy of genetic profiling depends upon the heritability and prevalence of the disease, as well as on the genotype frequency [74]. Besides, disease risk prediction based on multiple factors, each with weak effects, yields a continuum of risks, with only a small proportion of people at high risk, and the majority at a slightly higher or lower disease risk than the average disease risk in the population [75]. Gene-gene and gene-environment interactions may further influence the disease risk.

Moreover, none of the investigated new preventive measures has proven effective, as reflected by inconsistencies in reports from studies of anti-inflammatory agents, estrogens, nerve growth factors, ginkgo biloba, statins, amyloid vaccination, or antioxidants in preven- tion of $\mathrm{AD}[33,76,77]$. Experts are reluctant on the desirability and usefulness of predictive genetic testing for susceptibility to $\mathrm{AD}$ as long as there are no effective opportunities for prevention [78]. While the availability of interventions may be a criterion for the clinical implementation of tests, this does not hold for commercial applications. APOE genotyping is already commercially available in the genome scans offered by companies like Navigenics and deCODEMe [39]. The question remains whether healthcare should step into direct to consumer genetic testing and offer genetic testing with better counseling, or if it should refrain from it to make clear that these tests are relatively uninformative.

Treatment is similar for autosomal dominant or sporadic $\mathrm{AD}$. Several genes are good candidates expected to play a role in variability of drug disposition and pharmacodynamics in $\mathrm{AD}$, but the place of genetic profiling for clinical use is not determined yet. At present, therapeutic interventions for AD do not take into account the underlying genetic risk of the patient. Probably, the most important gain from genetic discoveries is the identification of biological pathways involved, which may improve our understanding of the pathological mechanism underlying AD. This in turn may lead to a better definition of disease subtypes and provide us with new targets for drug activity and more effective treatments, by targeting individuals who benefit most.

The limitations of our present understanding and knowledge of the disease, and therefore in prevention and treatment of at risk individuals, raise important ethical concerns regarding current applications of predictive genetic testing. As a result, genetic research and the potential implementation of genetic testing into clinical and public health practice are carefully monitored through the evaluation of the ethical, legal, and social issues $[79,80]$. The European Dementia Consensus Network (EDCON) has developed a consensus statement on ethics of dementia research [79]. Summarizing the report, top priority was given to the following issues: informed consent, disclosure of diagnosis of dementia, protection of patients, privacy of genetic data, and protection of relatives. Furthermore, it became evident that the most important step for further research is to promote a concerted involvement of researchers, patients' organizations, funding bodies, and politicians in defining research priorities.

In the future, applications of genetic testing in $\mathrm{AD}$ may play a role in the identification of presymptomatic individuals at high risk of developing the disease, the inclusion of genomic profiling into the armamentarium 
for early diagnosis of $\mathrm{AD}$, selection of effective interventions, and drug dosage adjustment as predicted by the genetic profiles. Genetic screening and predictive testing for $\mathrm{AD}$ will only become useful if genetic tests have sufficient predictive value and effective preventive measures will become available. Genetic variants with strong effects, both rare and common, either on their own or in interaction with other genes or environmental factors, might further improve the prediction of $\mathrm{AD}$ in asymptomatic individuals, yet most still need to be discovered. However, most research on genome-based applications in AD is still in the first phase of the translational research framework, which means that massive research is still needed before their implementation can be considered.

\section{ACKNOWLEDGMENTS}

This study was supported by the Health Care Insurance Board (CVZ) and the Centre for Medical Systems Biology (CMSB) in the framework of the Netherlands Genomics Initiative (NGI). ACJW Janssens was sponsored by the VIDI grant of the Netherlands Organization for Scientific Research (NWO) and a fellowship of the Erasmus University Medical Center.

Authors' disclosures available online (http://www.jalz.com/disclosures/view.php?id=272).

\section{REFERENCES}

[1] Alzheimer's Association (2009) 2009 Alzheimer's disease facts and figures. Alzheimers Dement 5, 234-270.

[2] Ferri CP, Prince M, Brayne C, Brodaty H, Fratiglioni L, Ganguli M, Hall K, Hasegawa K, Hendrie H, Huang Y, Jorm A, Mathers C, Menezes PR, Rimmer E, Scazufca M, Alzheimer's Disease I (2005) Global prevalence of dementia: a Delphi consensus study. Lancet 366, 2112-2117.

[3] Williamson J, Goldman JS, Mayeux R (2007) Genetic research and genetic testing in Alzheimer's disease: a view from the bridge. Nat Clin Pract Neurol 3, 356-357.

[4] Gatz M, Reynolds CA, Fratiglioni L, Johansson B, Mortimer JA, Berg S, Fiske A, Pedersen NL (2006) Role of genes and environments for explaining Alzheimer disease. Arch Gen Psychiatry 63, 168-174.

[5] Mayeux R, Saunders AM, Shea S, Mirra S, Evans D, Roses AD, Hyman BT, Crain B, Tang MX, Phelps CH (1998) Utility of the apolipoprotein E genotype in the diagnosis of Alzheimer's disease. Alzheimer's Disease Centers Consortium on Apolipoprotein E and Alzheimer's Disease. $N$ Engl $J$ Med 338, 506-511.

[6] Green RC, Cupples LA, Go R, Benke KS, Edeki T, Griffith PA, Williams M, Hipps Y, Graff-Radford N, Bachman D, Farrer LA, Group MS (2002) Risk of dementia among white and African American relatives of patients with Alzheimer disease. JAMA 287, 329-336.
[7] van der Flier WM, Scheltens P (2005) Epidemiology and risk factors of dementia. J Neurol Neurosurg Psychiatry 76(Suppl 5), v2-v7.

[8] Fratiglioni L, Launer LJ, Andersen K, Breteler MM, Copeland JR, Dartigues JF, Lobo A, Martinez-Lage J, Soininen H, Hofman A (2000) Incidence of dementia and major subtypes in Europe: A collaborative study of population-based cohorts. Neurologic Diseases in the Elderly Research Group. Neurology 54, S10-S15.

[9] van Duijn CM, Clayton D, Chandra V, Fratiglioni L, Graves AB, Heyman A, Jorm AF, Kokmen E, Kondo K, Mortimer JA, et al. (1991) Familial aggregation of Alzheimer's disease and related disorders: a collaborative re-analysis of case-control studies. EURODEM Risk Factors Research Group. Int J Epidemiol 20(Suppl 2), S13-S20.

[10] Courtney C, Farrell D, Gray R, Hills R, Lynch L, Sellwood E, Edwards S, Hardyman W, Raftery J, Crome P, Lendon C, Shaw H, Bentham P, Group ADC (2004) Long-term donepezil treatment in 565 patients with Alzheimer's disease (AD2000): randomised double-blind trial. Lancet 363, 2105-2115.

[11] Areosa SA, Sherriff F, McShane R (2005) Memantine for dementia. Cochrane Database Syst Rev, CD003154.

[12] Cacabelos R (2008) Pharmacogenomics and therapeutic prospects in dementia. Eur Arch Psychiatry Clin Neurosci 258(Suppl 1), 28-47.

[13] Brody DL, Holtzman DM (2008) Active and passive immunotherapy for neurodegenerative disorders. Annu Rev Neurosci 31, 175-193.

[14] Riemersma-van der Lek RF, Swaab DF, Twisk J, Hol EM, Hoogendijk WJ, Van Someren EJ (2008) Effect of bright light and melatonin on cognitive and noncognitive function in elderly residents of group care facilities: a randomized controlled trial. JAMA 299, 2642-2655.

[15] Khoury MJ, Gwinn M, Yoon PW, Dowling N, Moore CA, Bradley L (2007) The continuum of translation research in genomic medicine: how can we accelerate the appropriate integration of human genome discoveries into health care and disease prevention? Genet Med 9, 665-674.

[16] Bird TD (2008) Genetic aspects of Alzheimer disease. Genet Med 10, 231-239.

[17] Goate A, Chartier-Harlin MC, Mullan M, Brown J, Crawford F, Fidani L, Giuffra L, Haynes A, Irving N, James L, et al. (1991) Segregation of a missense mutation in the amyloid precursor protein gene with familial Alzheimer's disease. Nature 349, 704-706.

[18] Sherrington R, Rogaev EI, Liang Y, Rogaeva EA, Levesque G, Ikeda M, Chi H, Lin C, Li G, Holman K, et al. (1995) Cloning of a gene bearing missense mutations in early-onset familial Alzheimer's disease. Nature 375, 754-760.

[19] Levy-Lahad E, Wasco W, Poorkaj P, Romano DM, Oshima J, Pettingell WH, Yu CE, Jondro PD, Schmidt SD, Wang K, et al. (1995) Candidate gene for the chromosome 1 familial Alzheimer's disease locus. Science 269, 973-977.

[20] Rogaev EI, Sherrington R, Rogaeva EA, Levesque G, Ikeda M, Liang Y, Chi H, Lin C, Holman K, Tsuda T, et al. (1995) Familial Alzheimer's disease in kindreds with missense mutations in a gene on chromosome 1 related to the Alzheimer's disease type 3 gene. Nature 376, 775-778.

[21] Alzheimer Disease \& Frontotemporal Dementia Database, http://www.molgen.ua.ac.be/ADMutations, Accessed on October 6, 2009.

[22] Sherrington R, Froelich S, Sorbi S, Campion D, Chi H, Rogaeva EA, Levesque G, Rogaev EI, Lin C, Liang Y, Ikeda M, Mar L, Brice A, Agid Y, Percy ME, Clerget-Darpoux F, Piacentini 
S, Marcon G, Nacmias B, Amaducci L, Frebourg T, Lannfelt L, Rommens JM, St George-Hyslop PH (1996) Alzheimer's disease associated with mutations in presenilin 2 is rare and variably penetrant. Hum Mol Genet 5, 985-988.

[23] Corder EH, Saunders AM, Strittmatter WJ, Schmechel DE, Gaskell PC, Small GW, Roses AD, Haines JL, Pericak-Vance MA (1993) Gene dose of apolipoprotein E type 4 allele and the risk of Alzheimer's disease in late onset families. Science 261, 921-923.

[24] Saunders AM, Strittmatter WJ, Schmechel D, George-Hyslop PH, Pericak-Vance MA, Joo SH, Rosi BL, Gusella JF, CrapperMacLachlan DR, Alberts MJ, et al. (1993) Association of apolipoprotein E allele epsilon 4 with late-onset familial and sporadic Alzheimer's disease. Neurology 43, 1467-1472.

[25] Farrer LA, Cupples LA, Haines JL, Hyman B, Kukull WA, Mayeux R, Myers RH, Pericak-Vance MA, Risch N, van Duijn CM (1997) Effects of age, sex, and ethnicity on the association between apolipoprotein E genotype and Alzheimer disease. A meta-analysis. APOE and Alzheimer Disease Meta Analysis Consortium. JAMA 278, 1349-1356.

[26] Zuo L, van Dyck CH, Luo X, Kranzler HR, Yang BZ, Gelernter $\mathrm{J}$ (2006) Variation at APOE and STH loci and Alzheimer's disease. Behav Brain Funct 2, 13.

[27] Cupples LA, Farrer LA, Sadovnick AD, Relkin N, Whitehouse P, Green RC (2004) Estimating risk curves for first-degree relatives of patients with Alzheimer's disease: the REVEAL study. Genet Med 6, 192-196.

[28] Bertram L, McQueen MB, Mullin K, Blacker D, Tanzi RE (2007) Systematic meta-analyses of Alzheimer disease genetic association studies: the AlzGene database. Nat Genet 39, $17-$ 23. Last updated September 13, 2009, Accessed on October 7, 2009.

[29] Li H, Wetten S, Li L, St Jean PL, Upmanyu R, Surh L, Hosford D, Barnes MR, Briley JD, Borrie M, Coletta N, Delisle R, Dhalla D, Ehm MG, Feldman HH, Fornazzari L, Gauthier S, Goodgame N, Guzman D, Hammond S, Hollingworth P, Hsiung GY, Johnson J, Kelly DD, Keren R, Kertesz A, King KS, Lovestone S, Loy-English I, Matthews PM, Owen MJ, Plumpton M, Pryse-Phillips W, Prinjha RK, Richardson JC, Saunders A, Slater AJ, St George-Hyslop PH, Stinnett SW, Swartz JE, Taylor RL, Wherrett J, Williams J, Yarnall DP, Gibson RA, Irizarry MC, Middleton LT, Roses AD (2008) Candidate single-nucleotide polymorphisms from a genomewide association study of Alzheimer disease. Arch Neurol 65, 45-53.

[30] Waring SC, Rosenberg RN (2008) Genome-wide association studies in Alzheimer disease. Arch Neurol 65, 329-334.

[31] Patterson C, Feightner JW, Garcia A, Hsiung GY, MacKnight C, Sadovnick AD (2008) Diagnosis and treatment of dementia: 1. Risk assessment and primary prevention of Alzheimer disease. CMAJ 178, 548-556.

[32] Feldman HH, Jacova C, Robillard A, Garcia A, Chow T, Borrie M, Schipper HM, Blair M, Kertesz A, Chertkow H (2008) Diagnosis and treatment of dementia: 2. Diagnosis. CMAJ 178, 825-836.

[33] Waldemar G, Dubois B, Emre M, Georges J, McKeith IG, Rossor M, Scheltens P, Tariska P, Winblad B, Efns (2007) Recommendations for the diagnosis and management of Alzheimer's disease and other disorders associated with dementia: EFNS guideline. Eur J Neurol 14, e1-e26.

[34] Chertkow H (2008) Diagnosis and treatment of dementia: introduction. Introducing a series based on the Third Canadian Consensus Conference on the Diagnosis and Treatment of Dementia. CMAJ 178, 316-321.

[35] Hsiung GYR, Sadovnick AD (2007) Genetics and dementia:
Risk factors, diagnosis, and management. Alzheimers Dement 3, 418-427.

[36] Verlinsky Y, Rechitsky S, Verlinsky O, Masciangelo C, Lederer K, Kuliev A (2002) Preimplantation diagnosis for earlyonset Alzheimer disease caused by V717L mutation. JAMA 287, 1018-1021.

[37] Spriggs M (2002) Genetically selected baby free of inherited predisposition to early-onset Alzheimer's disease. J Med Ethics 28, 290.

[38] Caselli RJ, Beach TG, Yaari R, Reiman EM (2006) Alzheimer's disease a century later. J Clin Psychiatry 67, 1784-1800.

[39] Bonetta L (2008) Getting Up Close and Personal with Your Genome. Cell 133, 753-756.

[40] Green RC, Roberts JS, Cupples LA, Relkin NR, Whitehouse PJ, Brown T, Eckert SL, Butson M, Sadovnick AD, Quaid KA, Chen C, Cook-Deegan R, Farrer LA (2009) Disclosure of APOE genotype for risk of Alzheimer's disease. $N$ Engl $J$ Med 361, 245-254.

[41] The Lancet N (2009) Genetic testing for disease susceptibility: a risky business. Lancet Neurol 8, 775.

[42] Filley CM, Rollins YD, Alan Anderson C, Arciniegas DB, Howard KL, Murrell JR, Boyer PJ, Kleinschmidt-DeMasters BK, Ghetti B (2007) The genetics of very early onset Alzheimer disease. Cogn Behav Neurol 20, 149-156.

[43] Randall CN, Strasburger D, Prozonic J, Morris SN, Winkie AD, Parker GR, Cheng D, Fennell EM, Lanham I, Vakil N, Huang J, Cathcart H, Huang R, Poduslo SE (2009) Cluster analysis of risk factor genetic polymorphisms in Alzheimer's disease. Neurochem Res 34, 23-28.

[44] Reiman EM, Chen K, Caselli RJ, Alexander GE, Bandy D, Adamson JL, Lee W, Cannon A, Stephan EA, Stephan DA, Papassotiropoulos A (2008) Cholesterol-related genetic risk scores are associated with hypometabolism in Alzheimer'saffected brain regions. Neuroimage 40, 1214-1221.

[45] Licastro F, Porcellini E, Caruso C, Lio D, Corder EH (2007) Genetic risk profiles for Alzheimer's disease: integration of APOE genotype and variants that up-regulate inflammation. Neurobiol Aging 28, 1637-1643.

[46] Papassotiropoulos A, Wollmer MA, Tsolaki M, Brunner F, Molyva D, Lutjohann D, Nitsch RM, Hock C (2005) A cluster of cholesterol-related genes confers susceptibility for Alzheimer's disease. J Clin Psychiatry 66, 940-947.

[47] Corder EH, Huang R, Cathcart HM, Lanham IS, Parker GR, Cheng D, Smith S, Poduslo SE (2006) Membership in genetic groups predicts Alzheimer disease. Rejuvenation Res 9, 89-93.

[48] Christensen KD, Roberts JS, Royal CD, Fasaye GA, Obisesan T, Cupples LA, Whitehouse PJ, Butson MB, Linnenbringer E, Relkin NR, Farrer L, Cook-Deegan R, Green RC (2008) Incorporating ethnicity into genetic risk assessment for Alzheimer disease: the REVEAL study experience. Genet Med 10, 207214.

[49] Schipper HM (2009) Apolipoprotein E: Implications for AD neurobiology, epidemiology and risk assessment. Neurobiol Aging, in press.

[50] Kivipelto M, Rovio S, Ngandu T, Kareholt I, Eskelinen M, Winblad B, Hachinski V, Cedazo-Minguez A, Soininen H, Tuomilehto J, Nissinen A (2008) Apolipoprotein E epsilon4 magnifies lifestyle risks for dementia: a population-based study. J Cell Mol Med 12, 2762-2771.

[51] Serretti A, Olgiati P, De Ronchi D (2007) Genetics of Alzheimer's disease. A rapidly evolving field. J Alzheimers Dis 12, 73-92.

[52] Devanand DP, Pelton GH, Zamora D, Liu X, Tabert MH, 
Goodkind M, Scarmeas N, Braun I, Stern Y, Mayeux R (2005) Predictive utility of apolipoprotein E genotype for Alzheimer disease in outpatients with mild cognitive impairment. Arch Neurol 62, 975-980.

[53] Visser PJ, Verhey FR, Boada M, Bullock R, De Deyn PP, Frisoni GB, Frolich L, Hampel H, Jolles J, Jones R, Minthon L, Nobili F, Olde Rikkert M, Ousset PJ, Rigaud AS, Scheltens P, Soininen H, Spiru L, Touchon J, Tsolaki M, Vellas B, Wahlund LO, Wilcock G, Winblad B (2008) Development of Screening Guidelines and Clinical Criteria for Predementia Alzheimer's Disease. The DESCRIPA Study. Neuroepidemiology 30, 254265.

[54] Backman L, Small BJ (2007) Cognitive deficits in preclinical Alzheimer's disease and vascular dementia: patterns of findings from the Kungsholmen Project. Physiol Behav 92, 80-86.

[55] Ray M, Zhang W (2009) Integrating gene expression and phenotypic information to analyze Alzheimer's disease. $J$ Alzheimers Dis 16, 73-84.

[56] Gupta M, Kaur H, Grover S, Kukreti R (2008) Pharmacogenomics and treatment for dementia induced by Alzheimer's disease. Pharmacogenomics 9, 895-903.

[57] van der Vlies AE, Pijnenburg YA, Koene T, Klein M, Kok A, Scheltens P, van der Flier WM (2007) Cognitive impairment in Alzheimer's disease is modified by APOE genotype. Dement Geriatr Cogn Disord 24, 98-103.

[58] van der Flier WM, Schoonenboom SN, Pijnenburg YA, Fox NC, Scheltens P (2006) The effect of APOE genotype on clinical phenotype in Alzheimer disease. Neurology 67, 526527.

[59] Kester MI, Blankenstein MA, Bouwman FH, van Elk EJ, Scheltens P, van der Flier WM (2009) CSF biomarkers in Alzheimer's disease and controls: associations with APOE genotype are modified by age. J Alzheimers Dis 16, 601-607.

[60] Vasto S, Candore G, Duro G, Lio D, Grimaldi MP, Caruso C (2007) Alzheimer's disease and genetics of inflammation: a pharmacogenomic vision. Pharmacogenomics 8, 1735-1745.

[61] Small GW (2006) Diagnostic issues in dementia: neuroimaging as a surrogate marker of disease. J Geriatr Psychiatry Neurol 19, 180-185.

[62] Chiappelli M, Tumini E, Porcellini E, Licastro F (2006) Impaired regulation of immune responses in cognitive decline and Alzheimer's disease: lessons from genetic association studies. Expert Rev Neurother 6, 1327-1336.

[63] Ryan J, Scali J, Carriere I, Ritchie K, Ancelin ML (2008) Hormonal treatment, mild cognitive impairment and Alzheimer's disease. Int Psychogeriatr 20, 47-56.

[64] Ishunina TA, Swaab DF (2009) Hippocampal estrogen receptor-alpha splice variant TADDI in the human brain in aging and Alzheimer's disease. Neuroendocrinology 89, 187 199.

[65] Craig MC, Maki PM, Murphy DG (2005) The Women's Health Initiative Memory Study: findings and implications for treatment. Lancet Neurol 4, 190-194.

[66] Burns A (2009) Alzheimer's disease: on the verges of treatment and prevention. Lancet Neurol 8, 4-5.

[67] Masters CL, Beyreuther K (2006) Alzheimer's centennial legacy: prospects for rational therapeutic intervention targeting the Abeta amyloid pathway. Brain 129, 2823-2839.

[68] Risner ME, Saunders AM, Altman JF, Ormandy GC, Craft S, Foley IM, Zvartau-Hind ME, Hosford DA, Roses AD (2006) Efficacy of rosiglitazone in a genetically defined population with mild-to-moderate Alzheimer's disease. Pharmacogenomics J 6, 246-254.
[69] Salloway S, Sperling R, Gilman S, Fox NC, Blennow K, Raskind M, Sabbagh M, Honig LS, Doody R, van Dyck CH, Mulnard R, Barakos J, Gregg KM, Liu E, Lieberburg I, Schenk D, Black R, Grundman M, For the Bapineuzumab 201 Clinical Trial I (2009) A phase 2 multiple ascending dose trial of bapineuzumab in mild to moderate Alzheimer disease. Neurology 73, 2061-2070.

[70] Henderson ST, Vogel JL, Barr LJ, Garvin F, Jones JJ, Costantini LC (2009) Study of the ketogenic agent AC-1202 in mild to moderate Alzheimer's disease: a randomized, double-blind, placebo-controlled, multicenter trial. Nutr Metab (Lond) 6, 31 .

[71] Candore G, Balistreri CR, Grimaldi MP, Listi F, Vasto S, Chiappelli M, Licastro F, Colonna-Romano G, Lio D, Caruso C (2007) Polymorphisms of pro-inflammatory genes and Alzheimer's disease risk: a pharmacogenomic approach. Mech Ageing Dev 128, 67-75.

[72] Heshka JT, Palleschi C, Howley H, Wilson B, Wells PS (2008) A systematic review of perceived risks, psychological and behavioral impacts of genetic testing. Genet Med 10, 19-32.

[73] Roberts JS, Cupples LA, Relkin NR, Whitehouse PJ, Green RC, Group RS (2005) Genetic risk assessment for adult children of people with Alzheimer's disease: the Risk Evaluation and Education for Alzheimer's Disease (REVEAL) study. $J$ Geriatr Psychiatry Neurol 18, 250-255.

[74] Janssens AC, Aulchenko YS, Elefante S, Borsboom GJ, Steyerberg EW, van Duijn CM (2006) Predictive testing for complex diseases using multiple genes: fact or fiction? Genet Med 8, 395-400.

[75] Janssens AC, Moonesinghe R, Yang Q, Steyerberg EW, van Duijn CM, Khoury MJ (2007) The impact of genotype frequencies on the clinical validity of genomic profiling for predicting common chronic diseases. Genet Med 9, 528-535.

[76] Pomponi M, Bria P, Pomponi M (2008) Is Alzheimer's disease a synaptic disorder? J Alzheimers Dis 13, 39-47.

[77] Birks J, Grimley Evans J (2009) Ginko Biloba for cognitive impairment and dementia. Cochrane Database Syst Rev, CD003120.

[78] Post SG, Whitehouse PJ, Binstock RH, Bird TD, Eckert SK, Farrer LA, Fleck LM, Gaines AD, Juengst ET, Karlinsky H, Miles S, Murray TH, Quaid KA, Relkin NR, Roses AD, St George-Hyslop PH, Sachs GA, Steinbock B, Truschke EF, Zinn AB (1997) The clinical introduction of genetic testing for Alzheimer disease. An ethical perspective. JAMA 277, 832836.

[79] Olde Rikkert MG, van der Vorm A, Burns A, Dekkers W, Robert P, Sartorius N, Selmes J, Stoppe G, Vernooij-Dassen M, Waldemar G (2008) Consensus statement on genetic research in dementia. Am J Alzheimers Dis Other Demen 23, 262-266.

[80] van der Vorm A, Olde Rikkert MG, Vernooij-Dassen M, Dekkers W, Panel E (2008) Genetic research into Alzheimer's disease: a European focus group study on ethical issues. Int $J$ Geriatr Psychiatry 23, 11-15.

[81] St George-Hyslop P (2008) Genetics of dementia. Continuum Lifelong Learning Neurol 14, 29-48.

[82] van Swieten JC, Heutink P (2008) Mutations in progranulin (GRN) within the spectrum of clinical and pathological phenotypes of frontotemporal dementia. Lancet Neurol 7, 965-974.

[83] Thomas P, Fenech M (2007) A review of genome mutation and Alzheimer's disease. Mutagenesis 22, 15-33.

[84] Coon KD, Myers AJ, Craig DW, Webster JA, Pearson JV, Lince DH, Zismann VL, Beach TG, Leung D, Bryden L, Halperin RF, Marlowe L, Kaleem M, Walker DG, Ravid R, Heward CB, Rogers J, Papassotiropoulos A, Reiman EM, Hardy J, Stephan DA (2007) A high-density whole-genome association study 
reveals that $\mathrm{APOE}$ is the major susceptibility gene for sporadic late-onset Alzheimer's disease. J Clin Psychiatry 68, 613-618.

[85] Grupe A, Abraham R, Li Y, Rowland C, Hollingworth P, Morgan A, Jehu L, Segurado R, Stone D, Schadt E, Karnoub M, Nowotny P, Tacey K, Catanese J, Sninsky J, Brayne C, Rubinsztein D, Gill M, Lawlor B, Lovestone S, Holmans P, O'Donovan M, Morris JC, Thal L, Goate A, Owen MJ, Williams J (2007) Evidence for novel susceptibility genes for late-onset Alzheimer's disease from a genome-wide association study of putative functional variants. Hum Mol Genet 16, 865-873.

[86] Reiman EM, Webster JA, Myers AJ, Hardy J, Dunckley T, Zismann VL, Joshipura KD, Pearson JV, Hu-Lince D, Huentelman MJ, Craig DW, Coon KD, Liang WS, Herbert RH, Beach T, Rohrer KC, Zhao AS, Leung D, Bryden L, Marlowe L, Kaleem M, Mastroeni D, Grover A, Heward CB, Ravid R, Rogers J, Hutton ML, Melquist S, Petersen RC, Alexander GE, Caselli RJ, Kukull W, Papassotiropoulos A, Stephan DA (2007) GAB2 alleles modify Alzheimer's risk in APOE epsilon 4 carriers. Neuron 54, 713-720.

[87] Webster JA, Myers AJ, Pearson JV, Craig DW, Hu-Lince D, Coon KD, Zismann VL, Beach T, Leung D, Bryden L, Halperin RF, Marlowe L, Kaleem M, Huentelman MJ, Joshipura K, Walker D, Heward CB, Ravid R, Rogers J, Papassotiropoulos A, Hardy J, Reiman EM, Stephan DA (2008) Sorl1 as an Alzheimer's disease predisposition gene? Neurodegener Dis 5, 60-64.

[88] Poduslo SE, Huang R, Huang J, Smith S (2009) Genome screen of late-onset Alzheimer's extended pedigrees identifies TRPC4AP by haplotype analysis. Am J Med Genet B Neuropsychiatr Genet 150B, 50-55.

[89] Abraham R, Moskvina V, Sims R, Hollingworth P, Morgan A, Georgieva L, Dowzell K, Cichon S, Hillmer AM, O’Donovan MC, Williams J, Owen MJ, Kirov G (2008) A genome-wide association study for late-onset Alzheimer's disease using DNA pooling. BMC Med Genomics 1, 44.

[90] Bertram L, Lange C, Mullin K, Parkinson M, Hsiao M, Hogan MF, Schjeide BM, Hooli B, Divito J, Ionita I, Jiang H, Laird N, Moscarillo T, Ohlsen KL, Elliott K, Wang X, Hu-Lince
D, Ryder M, Murphy A, Wagner SL, Blacker D, Becker KD, Tanzi RE (2008) Genome-wide association analysis reveals putative Alzheimer's disease susceptibility loci in addition to APOE. Am J Hum Genet 83, 623-632.

[91] Beecham GW, Martin ER, Li YJ, Slifer MA, Gilbert JR, Haines JL, Pericak-Vance MA (2009) Genome-wide association study implicates a chromosome 12 risk locus for late-onset Alzheimer disease. Am J Hum Genet 84, 35-43.

[92] Carrasquillo MM, Zou F, Pankratz VS, Wilcox SL, Ma L, Walker LP, Younkin SG, Younkin CS, Younkin LH, Bisceglio GD, Ertekin-Taner N, Crook JE, Dickson DW, Petersen RC, Graff-Radford NR, Younkin SG (2009) Genetic variation in PCDH11X is associated with susceptibility to late-onset Alzheimer's disease. Nat Genet 41, 192-198.

[93] Harold D, Abraham R, Hollingworth P, Sims R, Gerrish A, Hamshere ML, Pahwa JS, Moskvina V, Dowzell K, Williams A, Jones N, Thomas C, Stretton A, Morgan AR, Lovestone S, Powell J, Proitsi P, Lupton MK, Brayne C, Rubinsztein DC, Gill M, Lawlor B, Lynch A, Morgan K, Brown KS, Passmore PA, Craig D, McGuinness B, Todd S, Holmes C, Mann D, Smith AD, Love S, Kehoe PG, Hardy J, Mead S, Fox N, Rossor M, Collinge J, Maier W, Jessen F, Schurmann B, van den Bussche H, Heuser I, Kornhuber J, Wiltfang J, Dichgans M, Frolich L, Hampel H, Hull M, Rujescu D, Goate AM, Kauwe JS, Cruchaga C, Nowotny P, Morris JC, Mayo K, Sleegers K, Bettens K, Engelborghs S, De Deyn PP, Van Broeckhoven C, Livingston G, Bass NJ, Gurling H, McQuillin A, Gwilliam R, Deloukas P, Al-Chalabi A, Shaw CE, Tsolaki M, Singleton AB, Guerreiro R, Muhleisen TW, Nothen MM, Moebus S, Jockel KH, Klopp N, Wichmann HE, Carrasquillo MM, Pankratz VS, Younkin SG, Holmans PA, O'Donovan M, Owen MJ, Williams J (2009) Genome-wide association study identifies variants at CLU and PICALM associated with Alzheimer's disease. Nat Genet 41, 1088-1093.

[94] Yu W, Gwinn M, Clyne M, Yesupriya A, Khoury MJ (2008) A navigator for human genome epidemiology. Nat Genet 40, 124-125. Last updated September 28, 2009, Accessed on October 4, 2009. 